\title{
Reversal of insulin resistance in type I diabetes after treatment with continuous subcutaneous insulin infusion
}

\author{
IBE LAGER, PETER LÖNNROTH， HENNING VON SCHENCK，ULF SMITH
}

\begin{abstract}
Insulin responsiveness was studied with the euglycaemic glucose clamp technique in seven patients with type I diabetes and in six control subjects matched for age and weight. The glucose disposal rate was significantly reduced in the diabetic subjects when they were receiving conventional insulin treatment compared with the control group, showing insulin resistance in the diabetics.

The diabetic patients were again studied after eight days of intensified metabolic control achieved with continuous subcutaneous insulin infusion. During the infusion a more physiological insulin regimen was used compared with their regular treatment, less of the total insulin dose being given as continuous infusion and more as bolus doses before meals. The insulin resistance in the diabetics was largely reversed after this improved metabolic control. Dose response studies showed an increased glucose disposal rate at all plasma insulin concentrations, including the maximum insulin concentration, indicating a predominant effect of the continuous infusion regimen at the postreceptor level.

The improved insulin effect seen with continuous subcutaneous insulin infusion could be due to the improved metabolic control achieved as well as the more physiological regimen.
\end{abstract}

\section{Introduction}

Insulin resistance has been found in different clinical states associated with hyperinsulinaemia such as obesity and type II diabetes. ${ }^{12}$ Increasing evidence now suggests that insulin resistance is present also in insulin treated type I diabetes. ${ }^{3-5}$ In vitro studies have shown that raised insulin concentrations per se are able to induce insulin resistance at both the receptor and the postreceptor level. ${ }^{6-8}$ Type I diabetics are often treated with long acting or intermediate acting insulin once or twice daily. This regimen will produce a "basal" hyperinsulinaemia over a large part of the 24 hours. The type of insulin regimen is important for insulin sensitivity and responsiveness in fat cells from these patients. ${ }^{9}$ Thus if the insulin regimen is changed to treatment with only short acting insulin given before each meal both insulin binding and responsiveness are increased in the adipose tissue. ${ }^{9} \mathrm{~A}$ drawback of this insulin regimen, however, is that the morning blood glucose concentrations are frequently too high. ${ }^{9}$ It has also been shown that high glucose concentrations could aggravate insulin resistance induced by high insulin

Department of Medicine II, Sahlgren's Hospital, Göteborg, Sweden IBE LAGER, MD, assistant

PETER LÖNNROTH, MD, assistant

ULF SMITH, MD, PHD, associate professor of internal medicine

Department of Clinical Chemistry, University of Linköping, Linköping, Sweden

HENNING VON SCHENCK, $M D$, associate professor of clinical chemistry

Correspondence and requests for reprints to: Dr Ulf Smith, Department of Medicine II, Sahlgren's Hospital, S-413 45 Göteborg, Sweden. concentrations in vitro. ${ }^{7}$ Optimal blood glucose control obtained with low basal insulin concentrations should therefore be the most appropriate treatment regimen in type I diabetes.

Continuous subcutaneous insulin infusion with portable insulin pumps is effective in controlling the diurnal blood glucose concentrations. ${ }^{10} 11$ Additionally, with this technique a greater proportion of the daily insulin requirement can be given as a bolus dose before meals, thereby maintaining lower basal insulin concentrations than with conventional treatment regimens. The aim of the present study was to evaluate whether insulin responsiveness was impaired in insulin treated type I diabetes and, if so, whether this could be improved by changing treatment from conventional insulin treatment to continuous subcutaneous insulin infusion.

\section{Patients and methods}

Seven patients (two women and five men) with type I diabetes according to the diagnostic criteria given by the National Diabetes Data Group ${ }^{12}$ were recruited from the diabetes outpatient clinic for the study. All patients were of normal weight and were considered to have stable diabetes. Their mean (SEM) haemoglobin A, concentrations at the time of inclusion in the study was $9.7(0.6) \%$ (table I). Their ages ranged from 22 to 51 years and the duration of diabetes from 4 to 34 years. They were all receiving regular treatment with a combination of short acting and intermediate acting insulin (Insulin Actrapid and Monotard, Novo, Denmark) twice daily. On average about $70 \%$ of the total insulin dose was given as intermediate acting and the remaining as short acting insulin (table I). Two patients (cases 4 and 5) had hypertension, which was treated with a combination of metoprolol, a cardioselective beta blocking agent, and hydralazine. This treatment was continued unchanged throughout the study. One of the patients (case 1) had mild proteinuria but a normal plasma creatinine concentration. Apart from this the patients did not exhibit any overt signs of diabetic complications. Further clinical details are given in table $\mathrm{I}$.

The results obtained in the diabetic patients were compared with those obtained in six normal control subjects of similar age and relative body weight (table I).

The diabetic patients were admitted to hospital for the study. Before admission a dietary history was recorded for each patient by an experienced dietitian. The patients were then given the same diet throughout their hospital stay. Their physical exercise habits were also maintained as closely as possible during the study. The patients spent nine days in hospital. During the first day their regular insulin dose was given. On days 2 and 9 euglycaemic glucose clamp studies were performed as described below. On the evening of the second day treatment with an insulin pump (Mill Hill 1001 HM, Muirhead Medical Products, London) was started and maintained to day 9. Insulin (Actrapid, Novo, Denmark) was then given subcutaneously through a syringe in the hypogastric region. The aim of the pump treatment was to achieve as good a blood glucose control as possible without hypoglycaemic attacks. In general terms, as little as possible of the total insulin dose should be given as continuous infusion and as much as possible as a bolus dose before meals. On average $60 \%$ of the total insulin dose was given before meals (table I). The insulin dose was adjusted according to the blood glucose concentrations.

It should be noted that the patients were not randomised for the order of treatment. The aim of the study-to compare the diabetics with a matched control group and then, if insulin resistance was present, to try to reverse this-made randomisation impossible.

Blood glucose concentrations were determined 30 minutes before and 60 minutes after each meal and once during the night (at 0400) with a reflectometer (Reflomat, Clinicon International GMBH, West Germany). We have found that blood glucose concentrations measured in this way by a trained person are closely correlated with concentra- 
TABLE I-Clinical characteristics of subjects studied

\begin{tabular}{|c|c|c|c|c|c|c|c|c|c|c|c|c|}
\hline \multirow{2}{*}{ Case No } & \multirow{2}{*}{ Sex } & \multirow{2}{*}{$\underset{\text { (years) }}{\text { Age }}$} & \multirow{2}{*}{$\begin{array}{c}\text { Duration of } \\
\text { diabetes } \\
\text { (years) }\end{array}$} & \multirow{2}{*}{$\underset{(\mathbf{k g})}{\text { Weight }}$} & \multirow{2}{*}{$\underset{(\mathrm{cm})}{\text { Height }}$} & \multicolumn{2}{|c|}{$\begin{array}{l}\text { Ordinary insulin dose } \\
\text { (IU/day) }\end{array}$} & \multicolumn{2}{|c|}{$\begin{array}{l}\text { Insulin dose during } \\
\text { continuous infusion } \\
\text { (IU/day) }\end{array}$} & \multirow{2}{*}{ Proteinuria } & \multirow{2}{*}{ Other treatment } & \multirow{2}{*}{$\begin{array}{c}\text { Haemoglobin } \\
\mathbf{A}_{1}(\%) \\
\text { (normal } \leqslant 7 \%)\end{array}$} \\
\hline & & & & & & $\begin{array}{l}\text { Intermediate } \\
\text { acting }\end{array}$ & $\begin{array}{l}\text { Short } \\
\text { acting }\end{array}$ & Basal dose & $\begin{array}{l}\text { Sum of } \\
\text { bolus doses }\end{array}$ & & & \\
\hline \multicolumn{13}{|c|}{ Diabetic group } \\
\hline 1 & $\mathrm{~F}$ & 22 & 10 & 73 & 167 & 28 & 18 & 16 & 28 & + & \multirow{6}{*}{$\begin{array}{l}\text { Metoprolol, } \\
\text { hydralazine } \\
\text { Metaprolol, } \\
\text { hydralazine }\end{array}$} & $10 \cdot 3$ \\
\hline 2 & $\mathrm{~F}$ & 24 & 4 & 53 & 163 & 20 & 24 & 22 & 35 & 0 & & $10 \cdot 8$ \\
\hline $\begin{array}{l}3 \\
4\end{array}$ & $\begin{array}{l}\mathbf{M} \\
\mathbf{M}\end{array}$ & $\begin{array}{l}25 \\
26\end{array}$ & $\begin{array}{r}5 \\
14\end{array}$ & $\begin{array}{l}66 \\
57\end{array}$ & $\begin{array}{l}178 \\
176\end{array}$ & $\begin{array}{l}32 \\
44\end{array}$ & $\begin{array}{r}14 \\
8\end{array}$ & $\begin{array}{l}18 \\
18\end{array}$ & $\begin{array}{l}28 \\
28\end{array}$ & $\begin{array}{l}0 \\
0\end{array}$ & & $\begin{array}{r}7 \cdot 3 \\
12 \cdot 1\end{array}$ \\
\hline 5 & $M$ & 38 & 33 & 68 & 170 & 46 & 8 & 19 & 25 & 0 & & $8 \cdot 1$ \\
\hline 6 & $M$ & 39 & 34 & 63 & 171 & 40 & 4 & 22 & 22 & 0 & & 8.8 \\
\hline $\begin{array}{l}0 \\
7\end{array}$ & $\stackrel{M}{M}$ & 51 & $\begin{array}{l}34 \\
21\end{array}$ & $\begin{array}{l}03 \\
59\end{array}$ & 167 & $\begin{array}{l}40 \\
24\end{array}$ & $\begin{array}{r}4 \\
28\end{array}$ & 22 & 32 & $\begin{array}{l}0 \\
0\end{array}$ & & $\begin{array}{r}8.8 \\
10 \cdot 7\end{array}$ \\
\hline \multicolumn{2}{|c|}{ Mean (SEM) } & $32(4)$ & $17(5)$ & $62(3)$ & $170(2)$ & $33 \cdot 4(3 \cdot 8)$ & $14.9(3.4)$ & $19 \cdot 2(0 \cdot 8)$ & $28 \cdot 3(1 \cdot 6)$ & & & $9.7(0.6)$ \\
\hline \multicolumn{13}{|c|}{ Control group } \\
\hline $\begin{array}{c}8 \\
8\end{array}$ & $M$ & 26 & & 70 & 180 & & & & & & & \\
\hline $\begin{array}{r}9 \\
10\end{array}$ & $M$ & $\begin{array}{l}26 \\
27\end{array}$ & & $\begin{array}{l}72 \\
84\end{array}$ & 186 & & & & & & & \\
\hline 11 & $M$ & 28 & & 89 & 190 & & & & & & & \\
\hline $\begin{array}{l}12 \\
13\end{array}$ & $\begin{array}{l}\mathrm{M} \\
\mathrm{F}\end{array}$ & $\begin{array}{l}28 \\
36\end{array}$ & & $\begin{array}{l}65 \\
62\end{array}$ & $\begin{array}{l}183 \\
172\end{array}$ & & & & & & & \\
\hline \multicolumn{2}{|c|}{ Mean (SEM) } & $29(2)$ & & $74(4)$ & $184(3)$ & & & & & & & \\
\hline
\end{tabular}

tions as determined with the glucose oxidase technique $(r=0.97$, $\mathrm{p}<0.001, \mathrm{n}=57$ ).

The glycaemic control achieved was estimated by calculating the mean diurnal blood glucose concentrations and the mean amplitude of the glucose excursions. ${ }^{13}$ Individual $M$ values were calculated according to the formula:

$$
M=\frac{\Sigma\left[10 \times \log \frac{B G}{4 \cdot 44}\right]}{n}
$$

where $\mathrm{BG}=$ blood glucose concentrations and $\mathrm{n}=$ number of observations. ${ }^{13} 14$ Glycosylated haemoglobin concentrations were estimated using prepacked microcolumns (Hemoglobin Quick Columns, Helena Laboratories, Beaumont, Texas, USA).

The healthy subjects were not admitted to hospital. Euglycaemic glucose clamp studies were performed in the morning after an overnight fast. The subjects were asked to maintain their normal diet and exercise habits and to refrain from smoking on the evening before the study.

\section{EUGLYCAEMIC GLUCOSE CLAMP STUDIES}

Euglycaemic glucose clamp studies were performed after an overnight fast according to the method described by de Fronzo et al. ${ }^{15}$ Insulin (Actrapid, Novo, Denmark) and glucose $(1.7 \mathrm{~mol} / \mathrm{l}$ (31 $\mathrm{mg} / 100 \mathrm{ml})$ ) were then infused through an antecubital vein with two variable infusion pumps. An antecubital vein in the contralateral arm was cannulated, and blood drawn from this was used to measure the blood glucose concentrations every 90 seconds with an automatically operating glucose sensor using the glucose oxidase technique (Gambro, Lund, Sweden). The aim was to maintain euglycaemia at $5.0 \mathrm{mmol} / 1(90 \mathrm{mg} / 100 \mathrm{ml})$. If the initial blood glucose concentration was above $5.0 \mathrm{mmol} / \mathrm{l}$ insulin was infused at a rate of $0.15 \mathrm{IU} / \mathrm{kg} / \mathrm{h}$ to reach euglycaemia; if the blood glucose concentration was below $5.0 \mathrm{mmol} / 1$ glucose was infused. When the blood glucose concentration was stabilised at $5.0 \mathrm{mmol} / \mathrm{l}$ the euglycaemic clamp study was started. The insulin infusion was then started with a priming infusion dose of $800 \mathrm{mU} / \mathrm{m}^{2} / \mathrm{min}$. This infusion rate was continuously decreased to $40 \mathrm{mU} / \mathrm{m}^{2} / \mathrm{min}$ during the first 10 minutes and then held constant. Glucose was administered at a variable infusion rate to maintain the blood glucose concentration at euglycaemia $(5 \mathrm{mmol} / \mathrm{l})$ for 80 minutes. In the diabetic subjects the euglycaemic clamp was then continued with insulin infusions at two higher rates $\left(240\right.$ and $1200 \mathrm{mU} / \mathrm{m}^{2} / \mathrm{min}$ ). Insulin was again infused with a decreasing priming dose during the first 10 minutes as described above. The euglycaemic clamp period lasted 80 minutes at each insulin infusion level. In the control subjects euglycaemic clamp studies were performed with only the low insulin dose.

Glucose uptake was calculated from the rate of glucose infusion between 60 and 80 minutes at each insulin infusion level. The blood glucose concentrations were maintained at $5.0 \mathrm{mmol} / 1 \pm 10 \%$ throughout the study.

Blood samples were drawn every 20 minutes for measurement of total and free insulin concentrations. Total insulin concentration was determined by radioimmunoassay (Phadebas, Pharmacia, Uppsala, Sweden), and free insulin concentration was determined after precipitation of insulin antibodies with macrosol (polyethylene glycol) according to the method of Kuzuya et al. ${ }^{16}$

\section{STATISTICS}

Comparisons between controls and diabetics were performed with Student's $t$ test for non-paired data. Data obtained before and after continuous subcutaneous insulin infusion in the diabetics were compared with Student's $t$ test for paired observations.

\section{Results}

\section{PATIENT TOLERANCE TO PUMP TREATMENT}

The patients tolerated the pump treatment well. Two patients (cases 4 and 6) experienced hypoglycaemic like symptoms on a few occasions during the pump treatment, but the blood glucose concentrations were never below $2.5 \mathrm{mmol} / 1(45 \mathrm{mg} / 100 \mathrm{ml})$ during these attacks. In one patient (case 7) glucose control deteriorated temporarily on day 7 owing to dysfunction of the pump.

\section{GLUCOSE CONTROL}

As shown in table II, control of diabetes was significantly improved during the pump period compared with during the regular insulin treatment regimen. Thus both mean diurnal glucose concentrations and $M$ values were significantly lower during the pump period. Also the mean glycaemic excursions tended to be lower during the pump treatment.

TABLE II-Mean diurnal glucose concentrations, $M$ values, 910 and mean amplitude of glucose excursions ${ }^{9}$ the day before the first and second euglycaemic clamps in type I diabetic subjects

\begin{tabular}{|c|c|c|c|c|c|c|}
\hline \multirow{2}{*}{ Case No } & \multicolumn{2}{|c|}{ Glucose (mmol/l) } & \multicolumn{2}{|c|}{$M$ value } & \multicolumn{2}{|c|}{$\begin{array}{l}\text { Mean amplitude of } \\
\text { glycaemic excursions }\end{array}$} \\
\hline & $\begin{array}{c}\text { First } \\
\text { clamp }\end{array}$ & $\begin{array}{l}\text { Second } \\
\text { clamp }\end{array}$ & $\begin{array}{l}\text { First } \\
\text { clamp }\end{array}$ & $\begin{array}{l}\text { Second } \\
\text { clamp }\end{array}$ & $\begin{array}{l}\text { First } \\
\text { clamp }\end{array}$ & $\begin{array}{l}\text { Second } \\
\text { clamp }\end{array}$ \\
\hline $\begin{array}{l}1 \\
2 \\
3 \\
4 \\
5 \\
6 \\
7\end{array}$ & $\begin{array}{r}7 \cdot 7 \\
8 \cdot 1 \\
7 \cdot 2 \\
12 \cdot 1 \\
9 \cdot 3 \\
10 \cdot 2 \\
8 \cdot 8\end{array}$ & $\begin{array}{l}6 \cdot 3 \\
7 \cdot 3 \\
7 \cdot 5 \\
8 \cdot 5 \\
5 \cdot 9 \\
8 \cdot 0 \\
6 \cdot 8\end{array}$ & $\begin{array}{r}26 \\
29 \\
22 \\
102 \\
50 \\
59 \\
50\end{array}$ & $\begin{array}{l}12 \\
20 \\
18 \\
41 \\
11 \\
21 \\
15\end{array}$ & $\begin{array}{l}4 \cdot 2 \\
5 \cdot 0 \\
3 \cdot 6 \\
6 \cdot 1 \\
6 \cdot 7 \\
6 \cdot 8 \\
9 \cdot 8\end{array}$ & $\begin{array}{l}4.5 \\
4.4 \\
3.4 \\
7.3 \\
3.3 \\
3.4 \\
3.5\end{array}$ \\
\hline $\begin{array}{l}\text { Mean } \\
\text { (SEM) } \\
\text { Significan }\end{array}$ & $\begin{array}{c}9 \cdot 1 \\
(0 \cdot 6) \\
p\end{array}$ & $\begin{array}{r}7 \cdot 2 \\
01^{(0 \cdot 3)}\end{array}$ & $\begin{array}{c}48 \cdot 3 \\
(10 \cdot 4)\end{array}$ & $01^{19 \cdot 7}$ & $\begin{array}{c}6 \cdot 0 \\
(0 \cdot 8) \\
0 \cdot 05\end{array}$ & $\begin{aligned} & 4.3 \\
&(0.5) \\
&<0.01\end{aligned}$ \\
\hline
\end{tabular}

Conversion: SI to traditional units-Glucose: $1 \mathrm{mmol} / \mathrm{l} \simeq 18 \mathrm{mg} / 100 \mathrm{ml}$. 


\section{EUGLYCAEMIC CLAMPS}

The blood glucose concentrations on the morning of the first clamp study, while patients were receiving conventional treatment, were significantly higher than those after pump treatment. Therefore, a longer insulin infusion time was required to reach euglycaemia $(5.0 \mathrm{mmol} / \mathrm{l})$ before the start of the first compared with the second clamp (64 (7) and 33 (4) minutes, respectively). As shown in fig 1, an insulin infusion rate of $40 \mathrm{mU} / \mathrm{m}^{2} / \mathrm{min}$ produced similar plasma concentrations of free insulin during the first and second glucose clamps in the diabetic patients $(70(9) \mathrm{mU} / 1$ and 61 (5) $\mathrm{mU} / 1$, respectively) as well as in the normal control group (51 (4) $\mathrm{mU} / 1$ ). The glucose uptake was significantly lower in the diabetic patients when they were receiving regular insulin treatment than in the controls (fig 1). After pump treatment, however, the glucose disposal rate was significantly higher $(p<0.0125)$ in the diabetic patients (average increase $41 \%$, fig 1). Thus physiological insulin concentrations were more effective in promoting glucose uptake in the diabetics after a period of intensified treatment, demonstrating an increased effect of insulin.

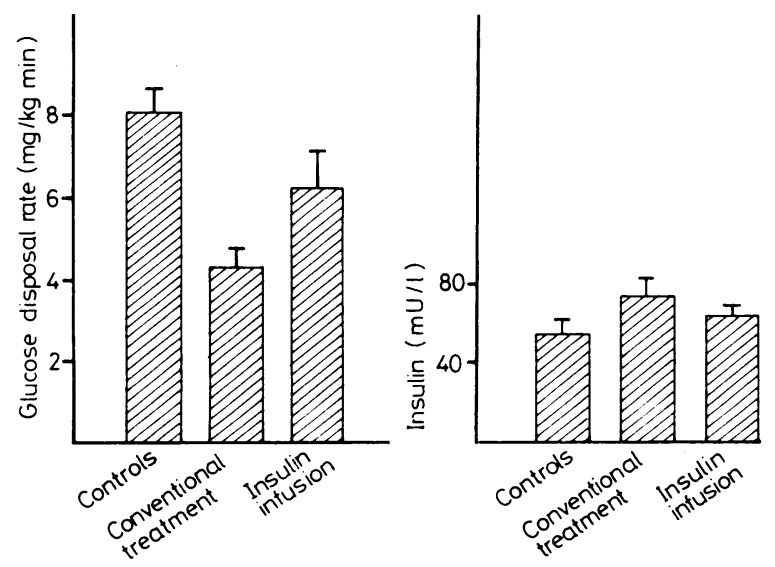

FIG 1-Glucose disposal rate and free insulin concentrations in six control subjects and seven diabetics receiving conventional insulin treatment and after continuous subcutaneous insulin infusion during euglycaemic glucose clamp with insulin infusion rate of $40 \mathrm{mU} / \mathrm{m}^{2} / \mathrm{min}$.

Conventional treatment $v$ controls: $\mathrm{p}<0.01$. Insulin infusion $v$ conventional treatment: $\mathrm{p}<0.0125$.

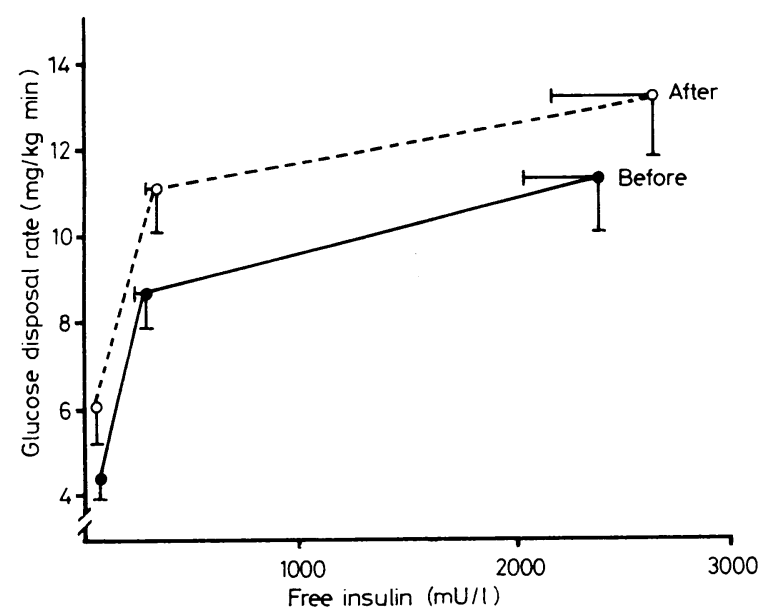

FIG 2-Dose response curves for glucose disposal rate in seven diabetics before and after continuous subcutaneous insulin infusion. The glucose disposal rate was significantly $(p<0.0125)$ higher after infusion at all plasma insulin concentrations studied.

To characterise further the effect of insulin after pump treatment in the diabetic subjects dose response studies were performed with two higher insulin infusion rates $\left(240\right.$ and $\left.1200 \mathrm{mU} / \mathrm{m}^{2} / \mathrm{min}\right)$. The glucose disposal rate increased significantly with increasing plasma insulin concentrations (fig 2). This increase was considerable for insulin concentrations up to about $500 \mathrm{mU} / 1$ and formed a plateau thereafter. The glucose disposal rates were an average of $20-30 \%$ higher during the second glucose clamp at both insulin infusion rates (fig 2). The plasma concentrations of free insulin reached were again similar on both occasions (at $240 \mathrm{mU} / \mathrm{m}^{2} / \mathrm{min} 305$ (38) and $348(46) \mathrm{mU} / \mathrm{l}$, and at $1200 \mathrm{mU} / \mathrm{m}^{2} / \mathrm{min} 2416$ (367) and 2669 (511) $\mathrm{mU} / \mathrm{l}$, respectively). The plasma concentrations of total insulin were higher than the concentrations of free insulin, but, again, no significant differences were found between the two studies at any of the three insulin infusion rates (data not shown). Thus there is no evidence that the insulin antibody concentration was changed by the period of continuous insulin infusion.

As we were not certain whether the individual maximum glucose disposal rate was reached ${ }^{17} \mathrm{~K}_{M}$ values were not calculated. When the maximum glucose disposal rate was considered to have been reached at the highest insulin infusion rate $\left(1200 \mathrm{mU} / \mathrm{m}^{2} / \mathrm{min}\right)$ the median effective dose could be calculated. This value tended to be lower after pump treatment compared with conventional treatment $(69 v 83 \mathrm{mU} / \mathrm{l}$, respectively) but the difference was not significant.

\section{Discussion}

The mean glucose disposal rate in the diabetics during regular insulin treatment, measured at an insulin infusion rate of $40 \mathrm{mU} / \mathrm{m}^{2} / \mathrm{min}$, was significantly lower than that found in the non-diabetic controls of similar age and weight. Thus the diabetic subjects showed insulin resistance when receiving this treatment regimen. This was apparent at mean insulin concentrations of 70 and $51 \mathrm{mU} / 1$ in the diabetics and controls, respectively. The presence of insulin resistance in type I diabetics has also been reported in other studies, ${ }^{3-5}$ but not in all. ${ }^{18}$ The conflicting results reported could be a function of the treatment regimen or degree of control, or both.

As in previous studies, ${ }^{19} 20$ treatment by continuous subcutaneous insulin infusion improved the metabolic control in the diabetics, even though their diabetes was considered to be well regulated with their regular insulin regimen. Their haemoglobin $A_{1}$ concentrations before pump treatment were also only slightly raised. The aim of the pump treatment was to obtain good metabolic control and to give a relatively large proportion of the total insulin requirement before meals. Thus the "basal" insulin concentrations (between meals) should be kept as low as possible. This goal was reached (table I). The insulin dose given as continuous infusion was only $40 \%$ of the diurnal requirement during the infusion regimen. The total daily amount of insulin given, however, was similar to that given before pump treatment.

The present findings show that improved control using a more physiological insulin regimen can reverse insulin resistance. We cannot decide from the present study whether the improved insulin effect noted during the infusion regimen was due to the altered regimen or to more rigorous glucose control per se. Recently, however, we have found that a high ambient glucose concentration further enhances the effect of insulin to reduce the number of binding sites in fat cells maintained in vitro. ${ }^{7}$ Thus, in the presence of insulin excess, raised glucose concentrations are important for the peripheral insulin effect. Furthermore, improved control of diabetes lowers the concentrations of counterregulatory hormones that may produce insulin resistance such as cortisol, catecholamines, and growth hormone. ${ }^{21-25}$

Apart from improved control per se being able to influence peripheral insulin responsiveness the insulin treatment regimen also appears to be of great, possibly predominant, importance. Several studies have shown that hyperinsulinaemia results in decreased insulin binding to the target cells. ${ }^{6-8}$ Treatment of diabetics with mainly long acting and intermediate acting insulin results in a prolonged "basal" hyperinsulinaemia, which seems to be responsible for the insulin resistance seen in fat cells in vitro. ${ }^{9}$ In agreement with this, the insulin resistance was reversed in this study when more of the daily insulin dose was given as short acting insulin in conjunction with meals and less as a continuous basal infusion.

As enhanced glucose utilisation has been found during pro- 
longed glucose clamp studies ${ }^{17}$ the clamp period was kept constant at each insulin infusion level in this study. In fact the total insulin infusion time was longer in the diabetics during the first clamp compared with the second as the fasting glucose concentrations were higher on the morning of the first clamp. The glucose disposal rate would, therefore, tend to be overestimated during the first euglycaemic study.

Insulin resistance could be an effect of both receptor and postreceptor perturbations. Owing to the presence of spare insulin receptors an evaluation of the insulin effect must include dose response studies at different plasma insulin concentrations. ${ }^{26}$ Insulin resistance due exclusively to reduced insulin binding causes a shift to the right of the dose response curve, whereas the maximum effect will be unchanged. On the other hand, insulin resistance at the postreceptor level leads to a decreased insulin effect at all insulin levels, including the maximum effect. ${ }^{27}$

The insulin sensitivity, defined as the insulin concentration producing half the maximum effect, tended to be increased after pump treatment. The main difference, however, was an increased glucose disposal rate at all insulin levels, indicating a predominant effect at the postreceptor level. Whether this was due to changes in the liver or in the peripheral tissues could not be evaluated from the present study as hepatic production of glucose was not measured.

Factors other than those already discussed have also been found to influence the insulin effect-for example, a change in diet or in the level of physical activity. ${ }^{28-30}$ Both of these factors, however, were kept as close as possible to the patients' regular habits during the study.

In summary, the present study shows that the insulin resistance in type I diabetics receiving regular insulin treatment can be largely reversed by continuous subcutaneous insulin infusion. The attenuated insulin resistance is probably an important reason for the improved metabolic control in spite of unchanged or even reduced daily insulin requirements. The increased responsiveness to insulin seen after even short term continuous infusion emphasises the importance of close supervision of the patients as their propensity for hypoglycaemia may be increased. Greater attention to this problem is also clearly warranted as unrecognised hypoglycaemic episodes may be more frequent than was previously realised. ${ }^{31}$ The improved insulin responsiveness may also be beneficial to the patients from another point of view as recent studies have indicated an association between insulin resistance and diabetic complications. ${ }^{32} 33$

This study was supported by the Swedish Medical Research Council (project 3506) and the Swedish Diabetes Association.

\section{References}

${ }^{1}$ Harrison LC, Martin FIR, Melick RA. Correlation between insulin receptor binding in isolated fat cells and insulin sensitivity in obese human subjects. $\mathcal{f}$ Clin Invest 1976;58:1435-41.

${ }^{2}$ Kolterman OG, Insel J, Saekow M, Olefsky JM. Mechanisms of insulin resistance in human obesity. Evidence for receptor and post-receptor defects. $\mathcal{F}$ Clin Invest $1980 ; 65: 1272-84$.

3 DeFronzo RA, Hendler R, Simonson D. Insulin resistance is a prominent feature of insulin-dependent diabetes. Diabetes $1982 ; 31: 795-801$

4 Harano Y, Ohgaku S, Hidaka H, et al. Glucose, insulin and somatostatin infusion for the determination of insulin sensitivity. $\mathcal{f}$ Clin Endocrinol Metab 1977;45:1124-7.

5 Pedersen $\mathrm{O}$, Hjöllund E. Insulin receptor binding to fat and blood cells and insulin action in fat cells from insulin-dependent diabetics. Diabetes $1982 ; 31$ : $706-15$.

- Gavin JR III, Roth J, Neville DM Jr, De Meyts P, Buell D. Insulindependent regulation of insulin receptor concentrations: a direct demonstration in cell culture. Proc Natl Acad Sci USA 1974;71:84-8.

${ }^{7}$ Lönnroth P, DiGirolamo M, Smith U. Influence of ambient glucose and insulin concentrations on adipocyte insulin binding. Metabolism 1983; 32:609-14.

${ }^{8}$ Amatruda JM, Newmeyer HW, Chang CL. Insulin-induced alterations in insulin binding and insulin action in primary cultures of rat hepatocytes. Diabetes $1982 ; 31: 145-8$.
9 Smith U. Regulation of the number of insulin receptors in human fat cells. Acta Endocrinol [Suppl] 1980;239:19-22.

10 Pickup JC, Keen H, Parsons JA, Alberti KGMM, Row AS. Continuous subcutaneous insulin infusion: improved blood-glucose and intermediate-metabolite control in diabetics. Lancet 1979;i:1255-7.

11 Tamorlane WV, Sherwin RS, Genel M, Felig P. Restoration of normal lipid and amino acid metabolism in diabetic patients treated with a portable insulin-infusion pump. Lancet $1979 ; \mathrm{i}: 1258-61$.

12 National Diabetes Data Group. Classification and diagnosis of diabetes mellitus and other categories of glucose intolerance. Diabetes $1979 ; 28$ : 1039-57.

13 Service FJ, Molnar GD, Rosevear JW, Ackerman E, Gatewood LC, Taylor WF. Mean amplitude of glycemic excursions, a measure of diabetic instability. Diabetes $1970 ; 19: 644-55$

14 Schlichtkrull J, Munck O, Jersild $M$. The $M$-value, an index of blood sugar control in diabetics. Acta Med Scand 1965;177:95-102.

${ }^{15}$ DeFronzo RA, Tobin JD, Andres R. Glucose clamp technique: a method for quantifying insulin secretion and resistance. Am f Physiol 1979;237: E214-23.

${ }^{16}$ Kuzuya M, Blix PM, Horowitz OL, Steiner DF, Rubenstein AH. Determination of free and total insulin and C-peptide in insulin-treated diabetics. Diabetes $1977 ; 26: 22-9$.

17 Doberne L, Greenfield MS, Schultz B, Reaven GM. Enhanced glucose utilization during prolonged glucose clamp studies. Diabetes $1981 ; 30$ 829-35.

18 Ginsberg HN. Investigation of insulin sensitivity in treated subjects with ketosis-prone diabetes mellitus. Diabetes 1977;26:278-83.

19 Steno Study Group. Effect of 6 months of strict metabolic control on eye and kidney function in insulin-dependent diabetics with back-ground retinopathy. Lancet $1982 ; \mathrm{i}: 121-3$.

${ }^{20}$ Mecklenburg RS, Benson JW, Becker NM, et al. Clinical use of the insulin infusion pump in 100 patients with type I diabetes. $N$ Engl $\mathrm{F} \mathrm{Med}$ $1982 ; 307: 513-8$.

${ }^{21}$ Cigolini M, Smith U. Human adipose tissue in culture. VIII. Studies on the insulin-antagonistic effect of glucocorticoids. Metabolism 1979;28: 502-10.

22 Rizza RA, Mandarino LJ, Gerich JE. Cortisol-induced resistance in man : impaired suppression of glucose production and stimulation of glucose utilization due to a post-receptor defect of insulin action. $\mathcal{F}$ Clin Endocrinol Metab 1982;54:131-8.

${ }^{23}$ Lönnroth $\mathrm{P}$, Smith U. $\beta$-adrenergic dependent downregulation of insulin binding in rat adipocytes. Biochem Biophys Res Commun 1983;112: 972-9.

${ }^{24}$ Deibert CD, DeFronzo RA. Epinephrine-induced insulin resistance in man. $\mathcal{F}$ Clin Invest 1980;65:717-21.

${ }^{25}$ Rizza RA, Mandarino LJ, Gerich JE. Effects of growth hormone on insulin action in man. Mechanisms of insulin resistance, impaired suppression of glucose production, and impaired stimulation of glucose utilization. Diabetes $1982 ; 31: 663-9$

${ }^{26}$ Kono T, Barham FW. The relation between the insulin-binding capacity on fat cells and the cellular response to insulin. $\mathcal{F}$ Biol Chem $1971 ; \mathbf{2 4 6}$. 6210-6.

${ }^{27} \mathrm{Kahn} \mathrm{CR}$. Insulin resistance, insulin insensitivity, and insulin unresponsiveness: a necessary distinction. Metabolism 1978;27:1893-902.

28 Olefsky JM, Saekow M. The effects of dietary carbohydrate content on insulin binding and glucose metabolism by isolated rat adipocytes. Endocrinology 1978;103:2252-63.

29 Bar RS, Gorden P, Roth J, Kahn CR, De Meyts P. Fluctuations in the affinity and concentrations of insulin receptors on circulating monocytes of obese patients. F Clin Invest 1976;58:1123-35.

${ }^{30}$ Pedersen O, Beck-Nielsen $\mathrm{H}$, Heding L. Increased insulin receptors after exercise in patients with insulin-dependent diabetes mellitus. $N$ Engl $\mathcal{F}$ Med 1980;302:886-92.

31 Simonson D, Sherwin RS. Insulin pump treatment reduces counterregulatory hormone responses to hypoglycemia in type I diabetes [Abstract]. Diabetes 1983;32, suppl 1:36A.

32. Maneschi F, Mashiter $\mathrm{K}$, Kohner $\mathrm{E}$. Insulin resistance and insulin deficiency in diabetic retinopathy of non-insulin-dependent diabetes. Diabetes $1983 ; 32: 82-7$.

${ }^{33}$ Hockaday TDR. Diabetic maculopathy [Editorial]. $\mathrm{Br}$ Med $F$ 1983;286: 915-6.

(Accepted 8 August 1983)

\section{Correction}

\section{Role of hepatic arterial embolisation in the carcinoid} syndrome

An error occurred in this paper by Dr P N Maton et al (1 October, p 932) The dosage of fenclonine stated in the fourth and fifth lines of the methods section should have read $500 \mathrm{mg}$ four times daily. 